\title{
Forum
}

\section{Soil Carbon Sequestration in Grazing Lands: Societal Benefits and Policy Implications}

\author{
Ronald F. Follett ${ }^{1}$ and Debbie A. Reed ${ }^{2}$
}

Authors are ${ }^{1}$ Research Soil Scientist, US Department of Agriculture Agricultural Research Service, Soil-Plant-Nutrient Research Unit, NRRC, Building D, Suite 100, 2150 Centre Avenue, Fort Collins, CO 80526, USA; and ${ }^{2}$ President/Director, DRD Associates, 415 Second Street, NE, Suite 300, Washington, DC 20002, USA.

\begin{abstract}
This forum manuscript examines the importance of grazing lands for sequestering soil organic carbon (SOC), providing societal benefits, and potential influences on them of emerging policies and legislation. Global estimates are that grazing lands occupy $\sim 3.6$ billion ha and account for about one-fourth of potential carbon (C) sequestration in world soils. They remove the equivalent of $\sim 20 \%$ of the carbon dioxide $\left(\mathrm{CO}_{2}\right)$ released annually into the earth's atmosphere from global deforestation and land-use changes. Atmospheric $\mathrm{CO}_{2}$ enters grazing lands soils through photosynthetic assimilation by green plants, subsequent cycling, and sequestration of some of that $\mathrm{C}$ as $\mathrm{SOC}$ to in turn contribute to the ability of grazing lands to provide societal (environmental and economic) benefits in every country where they exist. Environmental benefits provided include maintenance and well-being of immediate and surrounding soil and water resources, air quality, human and wildlife habitat, and esthetics. Grazing lands contribute to the economic well-being of those living on the land, to trade, and to exchange of goods and services derived from them at local, regional, or national levels. Rates of SOC sequestration vary with climate, soil, and management; examples and conditions selected from US literature illustrate the SOC sequestration that might be achieved. Public efforts, policy considerations, and research in the United States illustrate possible alternatives that impact grazing lands. Discussion of US policy issues related to SOC sequestration and global climate change reflect the importance attached to these topics and of pending legislative initiatives in the United States. Addressing primarily US policy does not lessen the importance of such issues in other countries, but allows an in-depth analysis of legislation, US Department of Agriculture program efforts, soil C credits in greenhouse gas markets, and research needs.
\end{abstract}

\section{Resumen}

Este manuscrito examina la importancia de las "tierras de pastoreo" en el secuestro de carbono orgánico en el suelo (COS) y en la provisión de beneficios a la sociedad, y las influencias potenciales que las políticas y legislación emergentes puedan tener sobre las características mencionadas. Según estimaciones globales, las tierras de pastoreo ocupan $\sim 3.600$ millones ha e incluyen aproximadamente un cuarto del potencial edáfico mundial de secuestro de carbono. Remueven el equivalente a $\sim 20 \%$ del dióxido de carbono $\left(\mathrm{CO}_{2}\right)$ liberado a la atmosfera anualmente por la deforestación y los cambios en el uso de la tierra. El $\mathrm{CO}_{2}$ atmosférico ingresa en las tierras de pastoreo mediante la asimilación fotosintética de plantas verdes, el ciclado subsecuente, y el secuestro de parte de ese C como COS que a la vez hace que las tierras de pastoreo puedan proveer beneficios (tanto ambientales como económicos) a la sociedad de todo país que contenga dichas tierras. Los beneficios ambientales que las mismas proveen incluyen el mantenimiento y bienestar de suelos y agua adyacentes y cercanos, la calidad del aire, el hábitat humano y para la fauna silvestre, y los valores estéticos. Las tierras de pastoreo contribuyen al bienestar económico de quienes viven de la tierra, permitiéndoles el comercio e intercambio de los bienes y servicios derivados de dichas tierras a nivel local, regional, o nacional. Las tasas de secuestro de COS varían con el clima, el suelo, y el manejo; ejemplos y condiciones seleccionadas de la literatura de los EE.UU. ilustran los niveles de secuestro de COS factibles de alcanzar. Esfuerzos públicos, consideraciones de políticas, e investigación en los EE.UU. ilustran las posibles alternativas que impactan las tierras de pastoreo. La discusión de temáticas asociadas con las políticas de los EE.UU. en relación con el secuestro de COS y el cambio climático global reflejan la importancia que se le asigna a estos temas y a la legislación pendiente en los EE.UU. El abordaje de las políticas de los EE.UU., no va en desmedro de la importancia de esta temática en otros países, pero permite un análisis detallado de la legislación, los programas del USDA, de los créditos de C edáfico en mercados climáticos, y de necesidades de investigación.

Key Words: 2008 Farm Bill, economic benefits, environmental benefits, legislation, pasture, rangelands, soil carbon sequestration

This publication is based upon work partially supported by the Agricultural Research Service (ARS) under the ARS GRACEnet (Greenhouse Gas Reduction through Agricultural Carbon Enhancement Network) Project.

Mention of a proprietary product is not an endorsement of the product by the Agricultural Research Service of US Department of Agriculture or the authors and does not imply its approval to the exclusion of other products.

This publication was made possible through support provided to the Global Livestock Collaborative Research Support Program by the Office of Agriculture, Bureau for Economic Growth, Agriculture and Trade, United States Agency for International Development under terms of Grant No. PCE-G-00-98-00036-00. The opinions expressed herein are those of the author(s) and do not necessarily reflect the views of the USAID.

Correspondence: Ronald F. Follett, US Department of Agriculture Agricultural Research Service, Soil-Plant-Nutrient Research Unit, NRRC, Building D, Suite 100, 2150 Centre Ave, Fort Collins, CO 80526, USA. Email: ronald.follett@ars.usda.gov

Manuscript received 3 November 2008; manuscript accepted 27 July 2009. 


\section{INTRODUCTION}

Grazing lands represent the largest and most diverse land resource in the world. More than half of the world's land surface is grazed. Nearly 100 of the world's countries have at least onehalf and 130 countries have at least one-third of their agricultural land area in grazing lands. Areawise, there are 27 countries with more than 30 million ha (Mha) and 9 countries having more than 100 Mha of grazing lands (Food and Agricultural Organization of the United Nations [FAO] 2004). In the United States, privately owned rangelands and pastures together account for $212 \mathrm{Mha}$ (Follett et al. 2001a, 2001b) with publicly owned grazing lands accounting for an additional 27 Mha within the conterminous United States (Sobecki et al. 2001) for a total of 239 Mha. A recent report, with an estimate similar to that of Sobecki et al. (2001), indicates the predominant use of grassland pasture and rangeland nationwide has declined from 267 Mha (35\%) in 1945 to about 236 Mha (31\%) of US land in 2002 (Economic Research Service of the US Department of Agriculture [USDA] 2007). This trend warrants further analysis because of the importance of grazing lands to provide ecosystem benefits to society, additional soil carbon sequestration, potential impacts to land use and land-use services sought by current and developing policies, and to assess the potential for continued delivery of these services (Table 1).

Grazing lands provide a wide array of goods and services of considerable economic, environmental, and social importance. Agriculturally, grazing lands provide the basis for the beef, dairy, and sheep industries in the United States. More than $85 \%$ of publicly owned lands in the west are grazed. Grazing lands usually are stocked with more than 60 million cattle and 8 million sheep, supporting a livestock industry that contributed over $\$ 35$ billion to the US economy in 2004 (National Agricultural Statistics Service of USDA 2008). Grazing lands function as watersheds where drinkable and potable water supplies originate as rainfall or snowmelt. Along with forests, grazing lands are a principal repository of biological diversity. Mayeux (2001) identifies that US grazing lands support upward to 20 million deer, 500000 pronghorn antelope, 400000 elk, 55000 wild horses and burros, and numerous wildlife species.

The objectives of this article are to examine the role of grazing lands for their 1) potential for soil carbon (C) sequestration; 2) contribution to societal benefits in relation to $\mathrm{C}$ sequestration, atmospheric greenhouse gases (GHG), and watershed functions; and 3) associated policy constraints, legislation, and research relative to the roles and ecosystem services of grazing lands.

A balance between economic and environmental goals of grazing-land managers is important to providing long-term societal benefits and services from the land resource. For example, grazing lands maintain the hydrologic cycle in large watersheds that supply water required for economic survival of downstream agricultural producers, towns, and cities. Maintenance of soil, vegetation, and hydrology of watersheds and within river basins near grazing lands provides wildlife habitat, slows rates of snowmelt and runoff, and helps prevent or reduce flooding. Disruption of grazing lands and their beneficial impacts on watersheds leads to the diminishment or loss of beneficial functions and impacts for all of society. Further, as federal and international efforts to slow, stop, and dramatically reduce emissions of GHG continue, the important role of grazing lands in protecting existing terrestrial C stocks, and potentially enhancing those stocks through changes in management, should gain increased attention and policy intervention.

\section{SOIL CARBON SEQUESTRATION IN GRAZINGLANDS}

Only recently have scientists begun to document soil C content and to study $\mathrm{C}$ dynamics on grazing lands maintained for many decades under different management regimes. Therefore,

Table 1. Glossary of relevant term and concepts. ${ }^{1}$

\begin{tabular}{|c|c|c|}
\hline Term & Definitions and explanations & Citation \\
\hline Grazing lands & Includes both rangelands and pastures. A set of highly diverse land resources rather than a land use per se. & \\
\hline Rangeland & $\begin{array}{l}\text { Land on which the historic climax plant community (i.e., late-succession stage vegetation) is present. The potential } \\
\text { natural vegetation (PNV) is principally native grasses, grasslike plants, forbs, or shrubs suitable for grazing and } \\
\text { browsing. }\end{array}$ & $\begin{array}{l}\text { NRCS (1992); } \\
\text { NRCS (1997) }\end{array}$ \\
\hline Pastureland & $\begin{array}{l}\text { Land used primarily for production of introduced or native forage plants for livestock grazing. Pastureland is } \\
\text { maintained in an ecological state where existing vegetative cover differs from the PNV and it usually requires and } \\
\text { receives more intensive management and production inputs than rangeland. Introduced plant species are often } \\
\text { used to maximize the land's resource value to produce forage. }\end{array}$ & NRCS (1992) \\
\hline Carbon sequestration & $\begin{array}{l}\text { The long-term storage of } \mathrm{C} \text { in the terrestrial biosphere, underground, or the oceans, so that the buildup of carbon } \\
\text { dioxide }\left(\mathrm{CO}_{2}\right) \text { in the earth's atmosphere will reduce or slow. }\end{array}$ & USDOE (2004) \\
\hline Societal benefits & Societal benefits can be broadly grouped into environmental and economic benefits. & \\
\hline $\begin{array}{l}\text { Environmental } \\
\text { benefits }\end{array}$ & $\begin{array}{l}\text { Benefits that maintain the well-being of the immediate and surrounding resources including for soil, water, and air } \\
\text { quality; for human and wildlife habitation; and for esthetics. }\end{array}$ & \\
\hline Economic benefits & $\begin{array}{l}\text { Benefits that contribute to the financial well-being of those living on the land as well as to trade and exchange of } \\
\text { goods and services associated with products derived from grazing lands at the local, regional, or national scale. }\end{array}$ & Kimble et al. (2007) \\
\hline Monitoring & The act of observing something and sometimes keeping a record of it (i.e., sequestered SOC). & \\
\hline Verification & $\begin{array}{l}\text { Comparing an activity, a process, or a product with the corresponding requirements or specifications. Does the } \\
\text { management activity result in the sequestration of the required or reported amount of newly sequestered SOC? }\end{array}$ & \\
\hline
\end{tabular}

${ }^{1}$ NRCS indicates the Natural Resources Conservation Service of the US Department of Agriculture; USDOE, US Department of Energy; and SOC, soil organic carbon. 
Table 2. Rangeland management effects on soil carbon sequestration rates for various ecosystems of the United States (data from Schuman and Derner 2004; Follett and Schuman 2005).

\begin{tabular}{|c|c|c|c|c|}
\hline Management & Ecosystem & Soil carbon $(C)$ sequestration & Location & Citation \\
\hline \multirow[t]{4}{*}{ Grazing } & Shortgrass steppe & $0.07-0.12 \mathrm{Mt} \mathrm{C} \cdot \mathrm{ha}^{-1} \cdot \mathrm{yr}^{-1}$ & Colorado & Derner et al. (1997) \\
\hline & $\begin{array}{l}\text { Northern mixed-grass } \\
\text { prairie }\end{array}$ & $0.30 \mathrm{Mt} \mathrm{C} \cdot \mathrm{ha}^{-1} \cdot \mathrm{yr}^{-1}$ & Wyoming, North Dakota & $\begin{array}{l}\text { Schuman et al. (1999); Reeder and } \\
\text { Schuman (2002); Frank (2004) }\end{array}$ \\
\hline & Southern mixed-grass prairie & No change in $\mathrm{C}$ & Oklahoma & Fuhlendorf et al. (2002) \\
\hline & Canadian prairie & Higher soil organic $\mathrm{C}$ when grazed & Canada & Henderson et al. (2004) \\
\hline \multirow[t]{3}{*}{ Nitrogen inputs } & $\begin{array}{l}\text { Nitrogen fertilization of } \\
\text { tall grass prairie }\end{array}$ & $1.6 \mathrm{Mt} \mathrm{C} \cdot \mathrm{ha}^{-1} \cdot \mathrm{yr}^{-1}$ & Kansas & Rice (2000) \\
\hline & $\begin{array}{l}\text { Nitrogen and sulphur } \\
\text { fertilization of } \\
\text { northern prairie }\end{array}$ & Increases of $0.45-0.72 \mathrm{Mt} \mathrm{C} \cdot \mathrm{ha}^{-1} \cdot \mathrm{yr}^{-1}$ & Saskatchewan & Nyborg et al. (1994) \\
\hline & $\begin{array}{l}\text { Legume interseeded } \\
\text { mixed-grass prairie }\end{array}$ & $0.33-1.56 \mathrm{Mt} \mathrm{C} \cdot \mathrm{ha}^{-1} \cdot \mathrm{yr}^{-1}$ & South Dakota & Mortensen et al. (2004) \\
\hline Fire & Tall grass prairie & $0.22 \mathrm{Mt} \mathrm{C} \cdot \mathrm{ha}^{-1} \cdot \mathrm{yr}^{-1}$ & Kansas & Rice (2000) \\
\hline \multirow[t]{6}{*}{$\begin{array}{l}\text { Restoration of } \\
\text { degraded lands }\end{array}$} & $\begin{array}{l}\text { Southern mixed-grass } \\
\text { prairie }\end{array}$ & $\begin{array}{l}\text { Moderate grazing, no change; heavy grazing, } \\
65 \% \text { decrease }\end{array}$ & Oklahoma & Fuhlendorf et al. (2002) \\
\hline & $\begin{array}{l}\text { Marginal cropland to } \\
\text { grazing land }\end{array}$ & $\begin{array}{l}\text { Restored soil } \mathrm{C} \text { to } 80 \% \text { of native rangeland } \\
\text { in } 100 \mathrm{yr}\end{array}$ & Sudan & Olsson and Ardö (2002) \\
\hline & Restored semiarid savanna & Increases of $1.9-2.75 \mathrm{Mt} \mathrm{C} \cdot \mathrm{ha}^{-1} \cdot \mathrm{yr}^{-1}$ & Argentina & Abril and Bucher (2001) \\
\hline & Southern tall grass prairie & Avg. $=0.45 \mathrm{Mt} \mathrm{C} \cdot \mathrm{ha}^{-1} \cdot \mathrm{yr}^{-1}$ & Texas & Potter et al. (1999) \\
\hline & $\begin{array}{l}\text { US Great Plains }\left(\mathrm{CRP}^{1}\right) \\
\text { introduced grasses }\end{array}$ & $0.8-1.1 \mathrm{Mt} \mathrm{C} \cdot \mathrm{ha}^{-1} \cdot \mathrm{yr}^{-1}$ & $\begin{array}{l}\text { Texas, Kansas, Nebraska, } \\
\text { North Dakota }\end{array}$ & $\begin{array}{l}\text { Gebhart et al. (1994); Follett et al. } \\
\text { (2001c) }\end{array}$ \\
\hline & Mined land reclamation & $1.95 \mathrm{Mt} \mathrm{C} \cdot \mathrm{ha}^{-1} \cdot \mathrm{yr}^{-1}$ & Wyoming & Stahl et al. (2003) \\
\hline \multirow[t]{3}{*}{$\begin{array}{l}\text { Woody plant } \\
\text { encroachment }\end{array}$} & $\begin{array}{l}\text { Southern mixed-grass } \\
\text { prairie }\end{array}$ & $\begin{array}{l}\text { Remove Prosopis glandulosa but no affect } \\
\text { on soil C }\end{array}$ & Texas & Teague et al. (1999) \\
\hline & Subtropical savanna & $\begin{array}{l}0.23 \mathrm{Mt} \mathrm{C} \cdot \mathrm{ha}^{-1} \cdot \mathrm{yr}^{-1} \text { under woody plants } \\
\text { (model predictions) }\end{array}$ & Texas & Hibbard et al. (2001) \\
\hline & Mesquite-acacia savanna & $0.14 \mathrm{Mt} \mathrm{C} \cdot \mathrm{ha}^{-1} \cdot \mathrm{yr}^{-1}$ & Texas & Liao (2004) \\
\hline
\end{tabular}

${ }^{1}$ CRP indicates Conservation Reserve Program.

knowledge of soil organic carbon (SOC) sequestration on grazing lands is limited. Predicting the sequestration potential is complicated by several factors, including wide regional and yearly climate variation; complexity of plant communities; presence and proportions of nitrogen (N)-fixing plants; type, species, and numbers of grazing animals; and management intensity and inputs (i.e., grazing and/or mowing frequency, fertilizing, and use of soil amendments). Analysis of 115 pastures and other grazing-land studies worldwide by Conant et al. (2001) indicates that soil C levels increase with improved management (i.e., fertilization, grazing management, and conversion from cultivation or native vegetation) and that the greatest $\mathrm{C}$ sequestration occurs during the first $40 \mathrm{yr}$ of implementation of the management practice. Except for a single irrigated study, the analysis by Conant et al. (2001) of the conversion of cultivated land to grazing land resulted in an average annual increase in SOC of 3-5\%.

Despite inherently low SOC sequestration rates, improved management of the world's extensive grazing lands provides a large $\mathrm{C}$ sequestration potential. Worldwide grazing-land area is estimated to be 3.5 billion ha (FAO 2004) to 3.7 billion ha (Lal 2004). Assuming an area of 3.5 billion ha, Follett and Schuman (2005) estimated sequestration to be $0.2 \mathrm{Pg} \mathrm{C} \cdot \mathrm{yr}^{-1}$ (1 petagram $=10^{15} \mathrm{~g}$ ), and Lal (2004) estimated sequestration for 3.7 billion ha to be $0.01-0.3$ (average $=0.16$ ) $\mathrm{Pg} \mathrm{C} \cdot \mathrm{yr}^{-1}$. Thus of the potential $\mathrm{C}$ sequestration in world soils estimated by Lal (2004) to be $0.4-1.2$ (average $=0.8) \mathrm{Pg} \mathrm{C} \cdot \mathrm{yr}^{-1}$, grazing-land soils would account for about $25 \%$ of this total, thus removing an estimated $0.7 \mathrm{Pg}$ of atmospheric carbon dioxide $\left(\mathrm{CO}_{2}\right)$. Data are slowly accumulating from various world regions about SOC sequestration in grazing lands and their response to management and climate. Grazing lands cover numerous ecoregions and climates around the world, each with unique characteristics affecting their rates of SOC sequestration and with less or more potential to respond to management. However, because of the difficulty of obtaining meaningful comparisons on a global basis, estimates aggregated within the United States will be used to provide information about potential rates of SOC sequestration in various ecosystems and responses to management.

\section{Rangelands}

Table 2 shows effects of management on SOC sequestration for selected US rangeland systems. Grazing facilitates litter decomposition through the effect of grazing and animal traffic (Schuman et al. 1999). Removing excess standing dead material by grazing animals hastens the onset of spring growth and photosynthesis by enhancing sunlight penetration and soil warming (LeCain et al. 2000). Most rangelands are $\mathrm{N}$ deficient and can respond to moderate $\mathrm{N}$ additions with increased production and water-use efficiency and some also show increased SOC sequestration (Table 2). Low to moderate $\mathrm{N}$ 
Table 3. Management effects on soil carbon (C) sequestration for pasturelands in the eastern United States (Schnabel et al. 2001). ${ }^{1}$

\begin{tabular}{|c|c|c|}
\hline Management activity & Intended management goal & Impact on $\mathrm{C}$ storage \\
\hline \multicolumn{3}{|l|}{ Animal management } \\
\hline Grazing lands & More $\mathrm{C}$ returned to soil for rapid incorporation & Increase SOC \\
\hline \multirow[t]{2}{*}{ Intensive grazing } & $\begin{array}{l}\text { With adequate moisture, intensive management } \\
\text { increases NPP, increased foot traffic breaks down residue }\end{array}$ & Increase SOC \\
\hline & With limited moisture, increased stocking can damage stands & Decrease SOC \\
\hline \multicolumn{3}{|l|}{ Forage management } \\
\hline \multirow[t]{2}{*}{ Replacing C3 grasses with C4 grasses } & At low to moderate fertility, increase NPP and reduce forage quality & Increase SOC \\
\hline & At high fertility, little change in NPP & $\begin{array}{l}\text { Little change in SOC. May not be } \\
\text { sustainable }\end{array}$ \\
\hline $\begin{array}{l}\text { Replace endophyte-infected fescue with } \\
\text { uninfected fescue }\end{array}$ & Increase forage quality & Decrease SOC \\
\hline Increase harvest frequency & Reduce NPP, increase forage quality & Decrease SOC \\
\hline Delay harvest or grazing & Reduce forage quality & Increase SOC \\
\hline \multicolumn{3}{|l|}{ Soil management } \\
\hline Liming & Increases phosphorus availability and NPP & Increases SOC \\
\hline \multirow[t]{2}{*}{ Phosphorus fertilization } & If phosphorus deficient, increase NPP & Increase SOC \\
\hline & If phosphorus is adequate or in excess, no change & No change \\
\hline \multirow[t]{2}{*}{ Nitrogen fertilization } & Low inherent fertility, increase NPP and forage quality & Increase SOC \\
\hline & $\begin{array}{l}\text { High inherent fertility; NPP and decomposition of SOC, } \\
\text { no change or increase }\end{array}$ & $\begin{array}{l}\text { No change, decrease, or increase in SOC, } \\
\text { depending on relative change in NPP and } \\
\text { decomposition }\end{array}$ \\
\hline Manuring & Increases NPP if fertility limits growth & Increases SOC \\
\hline Drainage & Increases NPP, increases SOC decomposition & Decreases SOC \\
\hline
\end{tabular}

${ }^{1} \mathrm{SOC}$ indicates soil organic carbon; NPP, net primary productivity.

additions are also predicted by the CCGRASS model (Van den Pol-van Dasselaar and Lantinga 1995) to lead to SOC increases. Increasing SOC sequestration on rangelands generally requires improved grazing management, introduction of legumes, and/or control of undesirable species. Good grazing management enhances rangeland productivity and maintains healthier rangelands (Schuman et al. 1999). Despite inherently low SOC sequestration rates, improved management of the world's extensive grazing lands provide a large $\mathrm{C}$ sequestration potential, which has implications for reducing GHG.

\section{Pasture}

The SOC status and changes in response to crop management have been the subject of much research and topic of numerous reviews and book chapters (Kononova 1961; Tate 1987; Jenkinson 1988; Follett and Wilkinson 1995; Burke et al. 1997; Scow 1997). However, relatively little of this research specifically addressed pasture management and SOC sequestration. A review of the literature and evaluation of the status and dynamics in grazing-land soils of the eastern United States led Schnabel et al. (2001) to evaluate the general effects of various conditions and pasture management practices on SOC sequestration. The magnitude and duration of management effects (Table 3) depend on several factors such as climate, soils, previous management, or potential net primary productivity. Converting marginal cropland to pastureland will increase SOC. Changes in how animals, plants, and soils are managed can also affect the balance between $\mathrm{C}$ inputs to the soil via plant fixation, and $\mathrm{C}$ losses from the soil to the atmosphere via decomposition. Where pasturelands are highly productive and SOC is already high, small or no increases in C storage may be expected. Larger increases can be made on marginally productive pasturelands by improving soil fertility or animal management to enhance plant productivity. Soil C sequestration is generally greater under grazed pastures than hayed pastures (Franzluebbers et al. 2000). Accurately measuring mass of SOC in grazed pastures is complicated by high spatial variability of the soil and vegetation, extensive land area, and a disproportionate redistribution of the nutrients in the dung and urine from grazing animals (West et al. 1989; Follett and Wilkinson 1995; Franzluebbers et al. 2000).

On pastures, even when livestock get most of their nutrients by grazing, efficient forage-based animal agriculture often requires both grazed pastures and stored forage. In temperate climates, pastures entirely or partially support animals for 5-12 mo annually. Stored forages are necessary given the growth habits of temperate grasses and legumes. Common cool-season forages produce more forage during the spring and the cooler fall months. Producers commonly stock pastures during July-August in the northern hemisphere. Periods of slow forage growth occur at different times and for different lengths of time in all climatic regions, but they do occur and managers must account for them.

\section{SOCIETAL AND ENVIRONMENTAL BENEFITS}

\section{Sequestration of Atmospheric $\mathrm{CO}_{2}$}

Among the environmental benefits recognized with $\mathrm{C}$ sequestration is to offset atmospheric $\mathrm{CO}_{2}$ emissions by storing $\mathrm{CO}_{2}$ long term in soil organic matter (SOM), thus helping to 
improve the soil's productivity. Practices and policies that encourage maintaining and improving soil $\mathrm{C}$ sequestration can consistently be associated with improved soil and water quality; reductions in silt loads and sediments into streams, lakes, and rivers; and improvements in air quality (Lal et al. 2003). The estimated SOC sequestration potential $(\sim 0.2 \mathrm{Pg}$ $\mathrm{C} \cdot \mathrm{yr}^{-1}$ ) in the world's grazing-land soils (Lal 2004; Follett and Schuman 2005) is equivalent to removing $\sim 0.7 \mathrm{Pg} \mathrm{CO}_{2} \cdot \mathrm{yr}^{-1}$ from the atmosphere, and if continued for $40 \mathrm{yr}$, as may be possible (Conant et al. 2001), is nearly $30 \mathrm{Pg} \mathrm{CO}_{2}$. Whether this $\mathrm{C}$ remains in storage, and for how long, and whether amounts can be increased through improved management, are important questions for additional research. Policies to support protecting and enhancing terrestrial $\mathrm{C}$ stocks may prove beneficial to the identified research needs, as well as to policies and programs aimed at reducing atmospheric concentrations of GHGs.

\section{Soil Erosion Control}

Risk of soil loss from grazing lands is generally less than from cropland, and magnitude depends on numerous factors. Climatic conditions such as drought, high winds, intense rainfall, and extreme runoff events result in the most serious amounts of wind and water erosion. Management that enhances the SOC in general results in increased protection of the soil from erosion. Conversely, poor management such as abusive grazing, intensive burning, or similar factors can result in SOC losses and the land being more vulnerable to soil erosion, especially on more steeply sloping land. Additionally, it is hypothesized that SOC and associated nutrients are transported by erosional processes into depositional sites and aquatic ecosystems where the SOC remains sequestered, contributes little to vegetative productivity, and reduces water quality. Lal (2007) estimates that approximately 0.8-1.2 Pg $\mathrm{C} \cdot \mathrm{yr}^{-1}$ of the displaced SOC is instead mineralized and emitted into the atmosphere as $\mathrm{CO}_{2}$. Even if SOC is sequestered in depositional sites, replacement of SOC on eroded sites is slow and the time lag between removal and replacement must be considered. Also, restoration of depleted SOC is hindered because of decreased soil fertility and biomass productivity. Poor or potentially abusive grazing management may decrease vegetative cover, increase soil erosion risks by wind and water, and heighten the potential to degrade water quality (Thurow et al. 1988; Lal 2001).

\section{Plant Biomass}

When nondisturbed natural conditions exist on large areas of grazing lands, the soil C pool is in equilibrium on these lands with inputs (litter, plant roots and root exudates, animal deposition, and on-site transport by run-on and dust) and outputs of C (off-site transport by wind and water erosion, decomposition, leaching, harvest, and animal removal). Conditions or management that decrease $\mathrm{C}$ input or increase its output will result in a SOC decline. Conversely, when conditions are reversed by management or other beneficial practices so that input exceeds output or there is decreased oxidation of SOM, then SOC can increase. Decline or increase in $\mathrm{C}$ inputs is caused by a decline or increase in aboveground biomass production and change in plant residue amount returned to the soil. Soil moisture and temperature regimes, soil erosion, leaching, and water-holding capacity are all important to SOC increases (or losses), the degree to which SOM is protected from oxidation, and potential for SOC to provide societal benefits.

\section{POLICIES RELATING TO SOIL CARBON SEQUESTRATION}

Attention to the contributions of grazing lands to GHG emissions and mitigation is warranted because of their large area and the focus of governments at all levels-international and domestic - to develop and implement mandatory GHG emissions reductions policies to combat global climate change. Soil C management is internationally recognized as being consistent with landscape-level land-management policies that provide multiple societal benefits (Kraxner et al. 2007). The benefits include improved air and water quality; soil tilth, fertility, and productivity; reduced soil erosion; enhanced water and nutrient content of soils; and enhanced wildlife habitat. Greater valuation of these vital ecosystem services is needed to understand better the economic benefits of contributions of healthy soils to society. Preservation of lands enhances soil resources and restores vital functions that we depend on, from food, feed, and fiber production to ecosystem services. Climatechange mitigation can thus be viewed as a synergistic or ancillary benefit, or if soil $\mathrm{C}$ management is a policy driver, as a key underlying goal of good land management.

To date, however, US federal climate change policies only encompass voluntary measures, though there is explicit acknowledgement that terrestrial sequestration mitigation options are advantageous. As noted in a 2006 Strategic Plan of the US government's Climate Change Technology Policy (US Department of Energy 2006): “Terrestrial sequestration represents a set of technically and commercially viable technologies that have the capability to reduce the rate of $\mathrm{CO}_{2}$ increase in the atmosphere. Given the size and productivity of the US land base, terrestrial sequestration has distinct economic and environmental advantages."

To date, various state and regional GHG reduction measures have been implemented or are being developed across the United States, some that include terrestrial sequestration offset options. California's legislature passed the Global Warming Solutions Act of 2006, the first mandatory state GHG emissions reduction plan enacted and that saw its first certified GHG emissions trade in February, 2008, when New Yorkbased Natsource Asset Management LLC bought 60000 tons of forest sequestration emission reductions from a private California landowner. However, no regional or state mandatory policy currently recognizes soil $\mathrm{C}$ sequestration by grazing lands as a certifiable offset.

The US-based Chicago Climate Exchange (CCX), a voluntary GHG emissions reduction program, issues offset contracts for soil $\mathrm{C}$ sequestration due to improved rangeland management practices, such as the use of sustainable stocking rates, rotational grazing, and seasonal use in eligible locations (http:// www.chicagoclimatex.com/). Offset contracts are expressed in mixed metric and English units, i.e., metric tons of $\mathrm{CO}_{2}$ per 
acre per year. The CCX offset award rates for rangeland projects vary from 0.12 to 0.52 metric tons of $\mathrm{CO}_{2}$ per acre per year, depending on project type and location, and require a minimum 5-yr contractual commitment.

Absent pending federal GHG emissions reduction policy, agricultural conservation programs such as the Grassland Reserve Program (GRP) and the Farm and Ranchlands Protection Program (FRPP) contribute to retention of existing SOC stocks and/or to enhanced C sequestration on public and private grazing lands. However, these emissions reductions occur as ancillary benefits to other policies and are not valuated as a climate-change mitigation measure. Whether to count and reward landowners for these ancillary benefits in future mandatory GHG emissions reductions policies has been significantly debated, but remains to be resolved.

Questions of additionality (i.e., would emissions reductions have happened anyway) and baselines (e.g., from which date, and within which boundaries, will emissions reductions be rewarded) must be decided as they relate to agricultural emissions reductions within a broader GHG emissions reductions policy. Because terrestrial sinks are by nature often not permanent, questions of how to reward these reductions have also been debated.

These policy discussions are currently underway in the federal legislative arena and no doubt will continue for the next several years. Based on bills and policies thus far introduced and debated and policy white papers from the US Senate and the US House of Representatives, it appears that soil C sequestration, including on grazing lands, may be recognized as a valid offset, subject to determinations of how they will be measured, monitored, and verified. Opportunities to reward emissions reductions achieved explicitly through USDA conservation programs are also being considered.

At the international level, a technical article on climate mitigation opportunities and challenges in the agricultural sector was the focus of a Technical Paper (FCCC/TP/2008/8) for the United Nations Framework Convention on Climate Change in Poznań, Poland (United Nations Framework Convention on Climate Change [UNFCCC] 2008). It was clear from workshop presentations, statements, and preceding and subsequent conferences of the parties (COP) submissions to the workshop that agricultural mitigation strategies are highly supported. Such practices and technologies are likely to be recognized and adopted as a solution in the post-2012 framework to be negotiated in Copenhagen in December 2009. Policies for GHG reductions from agriculture may be accomplished through national policies and international agreements (UNFCCC 2008). For example, a recent paper by the Food and Agricultural Organization of the United Nations (FAO) recognizes the importance of and is encouraging consideration of grasslands to be considered as part of a holistic approach (all gases, all sources and sinks) to land use and land-use change in the context of deliberations at COP 15 in Copenhagen and beyond (FAO 2009).

\section{Smart Growth and Agricultural Land Protection}

For future US policy development a comprehensive agricultural land-use assessment will be required to address whether, where, and how much land base in various grazing-land types is needed to deliver important societal benefits and ecosystem functions, including soil $\mathrm{C}$ sequestration. This assessment should include analysis of contributions of soil C management to GHG mitigation goals and other desirable ecosystem services and the resulting land base needed for such goals. Important questions include the land base needed to deliver desired services, geographic location of these lands in context to other lands and land uses (including urban, recreational, and aesthetic uses), and whether all or some of the lands must remain contiguous.

Current trends in land use show conversion of farmland and grazing land to urban uses is rising. Historically, population and economic growth have fueled land-development pressures that contribute to such losses. Recently, conversion to cropland, some of which is attributed to ethanol and biofuels mandates, have exacerbated losses of grazing lands (Searchinger et al. 2008). Greater understanding of the role of agricultural policies on land use and conversions is needed to ensure the US agricultural land base, including grazing lands, is sufficient to provide GHG, environmental, and ecosystem services as well as for the production of food, feed, fiber, and increasingly, biomass. Table 4 provides regional trends on the areas of US grassland pasture and range. The area in the southern plains (Texas, Oklahoma, and New Mexico, USA) increased from 1945 to 2002 by $10 \%$ (Table 4). All other US regions showed decreases and the area nationally decreased by $\sim 11 \%$ ( $\sim 30$ million ha). Central to these goals is to determine the services these lands deliver and which lands are valuable enough to protect and/or restore. If future policies rely upon desired environmental and GHG services from agricultural lands, including grazing lands, such services must better reflect the true value of lands that deliver them. This in turn requires fully rewarding activities, services, and societal contributions deemed desirable and important. So far, only limited assessments of the value of cobenefits of enhanced $\mathrm{C}$ stocks have been conducted.

Current grazing-land protection and easement programs point to an identified need or desire to protect these lands. However, these programs and protections are unevenly applied geographically, and their true impacts on land use and preservation are difficult to quantify, because they may result in increased land conversion elsewhere. In the absence of a comprehensive federal policy or initiative either to identify the highest priority lands for protection, and/or to establish minimal levels of protection, and minimal or maximal sequestration "needs," it is difficult to discern whether existing programs and trends will ensure or support the future delivery of required ecosystem services to society.

\section{USDA PROGRAMS}

USDA conservation policies and farmland protection and restoration programs for grazing lands to retain and enhance soil $\mathrm{C}$ stocks are included in existing public efforts to achieve soil C sequestration. The 1981 Farm Bill (formally the Agriculture and Food Act of 1981) laid the groundwork for the first federal farmland protection program and required an assessment of the impact of federally funded programs that converted farmland to nonagricultural uses. The 1996 Farm 
Table 4. Grassland pasture and range (noncropland and nonforest) by region in the conterminous United States, 1945-2002 (www.ers.usda.gov/ data/majorlanduses/; accessed 6 May 2009).

\begin{tabular}{|c|c|c|c|c|c|c|c|c|}
\hline Region $^{1}$ & 1945 & 1954 & 1964 & 1974 & 1982 & 1992 & 2002 & 1945 to 2002 \\
\hline & --------" & -----' & -------. & 1000 ha - & -------- & - & $-\cdots$ & Decr./Incr. \\
\hline Northeast & 4098 & 2908 & 2877 & 1372 & 1057 & 1209 & 1224 & $-70 \%$ \\
\hline Lake states & 4074 & 2544 & 3434 & 2141 & 2258 & 2136 & 2182 & $-46 \%$ \\
\hline Corn Belt & 10654 & 6811 & 8229 & 5541 & 5326 & 4988 & 5292 & $-50 \%$ \\
\hline Northern Plains & 33304 & 31728 & 32648 & 29657 & 28205 & 28205 & 28747 & $-14 \%$ \\
\hline Appalachian & 5516 & 4107 & 4362 & 3034 & 2559 & 2413 & 2530 & $-54 \%$ \\
\hline Southeast & 3515 & 4034 & 5084 & 4590 & 4203 & 3958 & 3352 & $-5 \%$ \\
\hline Delta States & 2920 & 3440 & 3817 & 3015 & 2991 & 2573 & 2528 & $-13 \%$ \\
\hline Southern Plains & 42527 & 42230 & 47906 & 45340 & 49487 & 48022 & 46842 & $10 \%$ \\
\hline Mountain & 137287 & 133907 & 127233 & 124419 & 123236 & 122828 & 122548 & $-11 \%$ \\
\hline Pacific & 22996 & 24220 & 21977 & 21756 & 21163 & 22047 & 21180 & $-8 \%$ \\
\hline Total United States & 266889 & 255930 & 257568 & 240865 & 240485 & 238378 & 236427 & $-11 \%$ \\
\hline
\end{tabular}

${ }^{1}$ Grassland and other nonforested pasture and range in farms plus estimates of open or nonforested grazing land not in farms.

Bill established the federal Farmland Protection Program (FPP) by providing $\$ 50$ million in matching funds to state, local, and tribal governments to purchase agricultural conservation easements to protect prime agricultural topsoil. The 2002 Farm Bill (the 2002 Farm Security and Rural Investment Act) reauthorized the FPP at $\$ 100$ million, and authorized land trusts and other nongovernmental organizations to participate in the cost-share program to keep productive farm and ranch land in use. This program has since been renamed the Farm and Ranch Lands Protection Program (FRPP).

In 2002, the GRP was created to protect and restore grassland, rangeland, pastureland, and shrubland for livestock grazing and other uses and prevent it from being converted to croplands or developed for urban use. A total of \$254 million was authorized for permanent, long-term easements or rental agreements of $10 \mathrm{yr}, 15 \mathrm{yr}$, or $30 \mathrm{yr}$.

The Environmental Quality Incentives Program (EQIP) established in the 1985 Farm Bill provides financial assistance to producers to install and maintain conservation practices and soil, water, and natural resource enhancing practices on productive agricultural lands and systems, including grassland, rangeland, pasture land, and lands used for livestock production. Locally identified problems are specifically targeted by EQIP and water-quality objectives given priority. Prescribed grazing systems in particular can help improve plant (forage) health, water quality and quantity, and reduce soil erosion, all while enhancing soil $\mathrm{C}$ stocks. In addition, the voluntary Conservation Innovation Grants (CIG) program awards EQIP funds and technical assistance to promote conservation and soil enhancement practices-including soil C sequestration-on private working lands, cropland, grassland, prairie land, improved pasture, and rangeland.

The 1991 Grazing Lands Conservation Initiative (GLCI) is a nationwide consortium of individuals and organizations working to protect and improve the management and stewardship of private and public grazing lands through local, state, and national partnerships. GLCI receives private support as well as support from USDA and the US Department of Interior.

Although these and other conservation programs help preserve grazing lands from development, they are not driven by soil C management policies or practices; nor has a thorough analysis of the ecosystem and environmental benefits delivered under these programs been completed.

One exception is that the Conservation Reserve Program explicitly identifies soil $C$ sequestration as a factor for enrollment selection in the Environmental Benefits Index (EBI). However, soil C sequestration is a subcategory criterion factor under the "Air Quality Benefits from Reduced Wind Erosion" category of the EBI. Because enhanced soil C stocks have multiple benefits, soil $\mathrm{C}$ sequestration could be included in virtually all the EBI categories as a criterion-or could constitute its own criterion for the EBI.

\section{THE 2008 FARM BILL}

The recently enacted Food, Conservation and Energy Act of 2008, i.e., the 2008 Farm Bill, contains new programs to help quantify environmental and societal benefits from grazing-land improvements. These conservation programs enable agricultural producers to increase soil $\mathrm{C}$ in grazing-land soils, but presently, there are no regional or state mandatory policies that recognize soil $\mathrm{C}$ sequestration by grazing lands as a certifiable offset. However, because of their large areas in every region, grazing lands are recognized for their potential to mitigate GHG emissions and provide environmental services in the 2008 farm bill by

- Authorizing the Environmental Service Markets Program within USDA. This program explicitly recognizes agriculture's role (and thus that of grazing lands) to provide environmental benefit to society, and seeks to prepare the sector to participate in emerging and existing markets. USDA is thus to establish a framework to measure benefits of environmental services that agricultural conservation and forest- and land-management activities provide. An Environmental Services Standards Board is established by the legislation to develop standards to quantify environmental services and to help develop agricultural credit markets and forest conservation activities that allow landowners to participate in existing and evolving markets. The Secretary is to first focus on carbon markets, with the goal of 
preparing agricultural producers to participate in existing and future voluntary and mandatory GHG markets. Technical guidelines are to be developed, including a verification process to consider the role of third parties, and to consult with other federal and state agencies and stakeholders.

- In anticipation of this program, Natural Resources Conservation Service of USDA (NRCS) has developed an NRCS Global Climate Change web page to link benefits of naturalresource and soil conservation to climate change and GHG emissions mitigation (NRCS 2008). Also being developed is an Environmental Credit Trading Information Series of fact sheets, with the first one addressing carbon credit trading on rangelands (NRCS 2007). The fact sheet is designed to prepare NRCS employees to assist producers and land managers to address environmental credit trading and other aspects of developing ecosystem services markets.

- The 2008 Farm Bill updates and extends the Conservation Security Program, established in the 2002 Farm Bill, and renames it the Conservation Stewardship Program. This program encourages comprehensive or systemwide stewardship of working agricultural lands with the use of annual and increasing financial incentives (based upon 5-yr contacts). The 2008 bill provides an additional \$1.1 billion more in funding to enroll $\sim 5.3 \mathrm{Mha} \cdot \mathrm{yr}^{-1}$, including private grassland, prairie land, improved pasture land, rangeland, and agroforestry, and also other lands used for livestock production.

- Mandatory funding for the Farmland Protection Program was doubled to $\$ 773$ million, and EQIP funding was raised by $\$ 3.4$ billion. More user-friendly certification processes to determine program eligibility are developed for both programs.

- New language is developed within the Conservation Innovation Grants (CIG) program to support projects for efficient and effective transfer of innovative soil carbon storage technologies.

- Changes to the Grassland Reserve Program (GRP) are targeted to help landowners and operators restore and protect grassland and rangeland and preserve healthy grazing lands. Short-term rental contracts and long-term easements are now available through this program and an additional $\$ 300$ million in new funding was included to enroll an additional 5.3 Mha by 2012 .

- Finally, a new Biochar Research and Demonstration program was enacted. Biochar is a biomass-derived black carbon formed from pyrolysis or gasification of biomass in the absence of oxygen. It is reported to have agronomic and soil-enhancing benefits as a soil amendment (Lehmann et al. 2006) and to serve as a stable, long-term form of terrestrial carbon (Kuzyakov et al. 2009).

\section{OTHER US LEGISLATION}

The 110th Congress devoted increased attention to global climate change through mandatory, national GHG emissions reductions policies and programs. In the Senate, mandatory cap-and-trade legislation was introduced by Senators Joseph
Lieberman (I-CT) and John Warner (R-VA) and achieved prominence as the first such bill to pass through its full committee of jurisdiction (S.2191, America's Climate Security Act of 2007; Banks 2008). S.2191 passed the full Senate Environment and Public Works Committee in December 2007 and was debated in the full Senate in June 2008. The bill established a cap on roughly $82 \%$ of total US GHG emissions, resulting in effectively lowering them by approximately $11 \%$ and $25 \%$ below 1990 levels by 2030 and 2050, respectively (US Environmental Protection Agency [USEPA] 2008). S.2191 established a market-based trading system for domestic offsets. Offsets are GHG emissions reductions credits generated by entities or sectors not regulated by the bill or policy. The agricultural sector would not be regulated and explicitly qualified as a voluntary sector that could generate emissions reductions offset credits that a capped or regulated entity can buy or trade. Income generation from these offset credits is estimated to be in the billions of dollars annually under a fully functioning cap-and-trade system (Orszag 2007). S.2191 included set-aside allowances for agricultural and forestry sequestration activities. The Clean Air Task Force estimated the allowances provision was worth an additional $\$ 110$ billion by 2030 to the agricultural and forestry sectors (Banks 2008). Carbon sequestration management activities on grazing lands are cited as eligible for offset or allowance credits awards in S.2191, pending development of regulations and procedures to implement the programs.

At the start of the 111th US Congress, leadership in both the House of Representatives and the Senate, with support from the President, indicated that passing mandatory legislation to curb US emissions of GHG is of high priority. The legislative process began in the House with a draft bill from Chairman Henry Waxman of the House Energy and Commerce Committee and Energy and Environment Subcommittee Chairman Edward Markey. The House has now passed HR 2454 (Waxman-Markey; US House of Representatives 2009). In the Senate, committees of jurisdiction have begun having hearings on potential legislation, with the Senate's leadership promising floor votes on a bill before summer 2010. It is widely believed the United States will enact or implement mandatory nationwide GHG emissions reductions policies within 1-3 yr.

\section{FUTURE PUBLIC POLICIES}

Important to promoting soil C management on grazing lands is its inclusion as a category of eligible emissions reductions offsets within mandatory emissions reductions policies. Soil carbon management has multiple societal benefits, including GHG emissions reductions in cap-and-trade programs, as an offset to provide cost savings in terms of reducing GHG emissions at a net savings to society (McKinsey 2007), and by reducing compliance costs for capped sectors and for the capand-trade system (USEPA 2008).

McKinsey and coworkers launched a 2007 mapping initiative to analyze costs and potentials of different US GHG emissions reductions options over 25 yr. In their 2007 report, they concluded that "the savings created by these options would more than offset the costs of implementing them." Soil management practices to expand and enhance carbon sinks 
were specifically cited as an "economically sensible strategy" for reducing US GHG emissions. The obvious conclusion is that soil C sinks are good public policy as a GHG abatement option that can be achieved across the general US landscape, including rangelands, with existing technologies and methodologies, at low costs, or net cost savings.

\section{SOIL CARBON CREDITS IN GHG MARKETS}

Grazing lands can provide valuable GHG emissions reductions and enhanced soil C sinks on behalf of society as a means of providing a source of low-cost, readily implemented, highimpact offset credits. Offset credits are a viable, important costcontainment mechanism for cap-and-trade approaches to mandatory GHG emissions reductions programs. Virtually every major economic analysis of how the US can begin to slow, stop, and reverse its growing emissions of GHG relies upon soil C sinks as a near-term, low-cost pool of reductions to atmospheric GHG emissions. Soil carbon credits from grazing lands are a valuable offset component, help increase availability and diversity of low-cost compliance credits within a cap-andtrade program, reduce compliance costs, improve market liquidity, and provide an available transitional strategy while capitol stock turnover, changes in investment decisions, and alternative energy technologies are developed and implemented. As a noncapped sector, grazing lands can participate in GHG emissions programs to create emissions reductions or enhanced soil sinks on a voluntary basis, to keep economic impacts low, and to provide important income-generation opportunities. A cap-and-trade program must take advantage of these high-impact GHG mitigation opportunities from grazing lands by providing a comprehensive, rigorous, yet streamlined approach to allow producer participation without onerous or unduly complicated requirements.

In their analysis of economic, environmental, and societal benefits of soil C management, Mooney and Williams (2007) indicate that though the value is considerable, quantifying benefit value is difficult. At the policy level, McCarl and Schneider (2001) concluded a federal level GHG mitigation policy rewarding agricultural and forestry mitigation practices, though providing higher economic benefits for agricultural producers, would cause higher costs to consumers. Subsequently, it was shown that if the policy is constructed to maximize offset provision by the agricultural sector, a cap-and-trade program provided substantial net benefits to US farmers and ranchers-based particularly on the sale of soil C offset credits (McCarl 2007).

Plantinga and $\mathrm{Wu}$ (2003) concluded that a policy to encourage cropland conversion to forestland achieved about the same cost benefits from reduced soil erosion and enhanced wildlife habitat as the cost of program implementation, and soil $\mathrm{C}$ sequestration benefits were additional. Others have determined that water quality cobenefits of soil $\mathrm{C}$ sequestration are significant (Pattanayak et al. 2002; Greenhalgh and Sauer 2003).

Feng et al. (2007) identified two types of cobenefits associated with carbon sequestration in agricultural soils: 1) environmental cobenefits ancillary to the carbon reduction benefit (e.g., reduced soil erosion and enhanced water retention), and 2) "economic vitalities" that improve net return to producers (e.g., income generated by the practice in excess of the opportunity cost). The authors concluded that to be socially efficient, size and geographical impact of cobenefits highly depend on policy construct and the targeting for both $\mathrm{C}$ sequestration and cobenefits.

Existing USDA Conservation programs deliver multiple ancillary benefits to society and to agriculture. Thus it is possible for additional GHG benefits to be achieved and to be rewarded as a consequence of these programs and to help incentivize and duly reward ecosystem services and activities valued by society. Payments for ongoing environmental and ecological services will also help to keep land values high enough to reflect these services and benefits, and further protect grazing lands from development pressures.

\section{FUTURE USDA PROGRAMS}

Market-based incentives in support of agricultural conservation activities and terrestrial sequestration on public and private lands, including grazing lands, can provide income-generation potential to accomplish a suite of environmental, natural resource, and ecosystem benefits enjoyed by society at large as well as the agricultural sector. Historically, federal funding for agricultural conservation programs has been growing. A historical analysis of farm program spending (Zulauf 2005) indicates that since the 1960s, conservation programs accounted for about a $10 \%$ share of farm bill spending, but prior to the 2002 Farm Bill conservation spending was focused on land retirement programs. The 2002 Farm Bill changed the focus to promoting environmentally beneficial practices on working lands, and boosted conservation spending to approximately $16 \%$ of Farm Bill spending. The 2008 Farm Bill has increased total spending for conservation programs by nearly $\$ 4$ billion, but as a share of total spending, this amount dropped to nearly $12.5 \%$ (Orszag 2008). Despite this tend, many conservation programs remain underfunded and oversubscribed. Policies to tap the market potential of existing and future GHG policies as a means to incentivize and monetarily award soil C management and other agricultural activities are warranted.

\section{RESEARCH RECOMMENDATIONS}

The value and synergy between carbon management and soil C content should be a "cementing element" driving various international and federal land-use and environmental policies (Kimble et al. 2007; Kraxner et al. 2007). Analyses of how to harmonize agricultural land management, including GHG and soil C management policies, with other agricultural and climate-change mitigation policies should be further developed at the landscape scale in order to avoid duplication and unintended consequences and to maximize benefits of research and policy implementation at national and global scales. Interdisciplinary research with the intent to develop and implement a suite of integrated, holistic management systems are required to achieve the desired outcomes of such policies. 
An integrated assessment of existing and future agricultural land management and use across the US landscape, and the suite of services and benefits delivered by these lands, to include future demands for services (such as soil C sequestration) is needed to inform policy development as well as ensure that a minimal land base of these agricultural lands are retained to provide the services demanded by and necessary to support human health and the soil resource upon which we depend. This should include an assessment also of whether acreage is the sole determining factor, or whether key areas or corridors are important to certain needs.

There is need for continued investments in accurate, up-todate, spatially referenced soil information databases to predict changes in soil C stocks at all scales and resolutions accurately. Continued and increased investments in these databases will enable agricultural offsets credits to be fully integrated into GHG markets by reducing the uncertainty of these measurements. Such database information can help increase net returns to agricultural producers in carbon markets, while also ensuring the robustness and accuracy of the carbon markets and offset projects.

\section{A Role for USDA}

- Continue to develop cost-effective, accurate monitoring and verification technologies to measure changes in GHG emissions or emissions reductions, including changes in soil C stocks on croplands, conservation lands, grazing lands, grasslands, and pasture lands. This will be particularly important to ensure maximal sale value for soil $\mathrm{C}$ credits in market-based GHG emissions reduction systems.

- Advance the GRACEnet (Greenhouse Gas Reduction Through Agricultural Carbon Enhancement Network) program of the Agricultural Research Service that currently includes $\sim 30$ Agricultural Research Service locations nationally that use standard protocols to evaluate status and direction of soil $\mathrm{C}$ change in typical and alternative agricultural systems while building a national database and developing and evaluating computer models to assess management effects (http://www.ars.usda.gov/research/ GRACEnet). Continued remeasurement of management effects (now for $5+$ yr) at many locations is providing information about soil $\mathrm{C}$ and also about management effects on soil nitrous oxide and soil methane emissions (two important GHG).

- Pilot test a National Soil Carbon Measurement and Modeling Network that combines the CENTURY model with a subset of National Resource Inventory points to collect 1000 actual soil samples per year over a 5-yr cycle. Once implemented, the Network will support 5000 soil measurements to be taken every $5 \mathrm{yr}$ and remeasure each sampling site for soil $\mathrm{C}$ changes over time. The system would serve as a long-term sustainable inventory activity and provide improved accuracy of and reduced uncertainty estimates of soil C sequestration from field to national scales.

- Improve on-farm whole-system GHG accounting systems and methodologies.

- Establish criteria to determine how to calculate baselines, additionality, and leakage for agricultural terrestrial seques- tration projects within ecosystem services and carbon markets. This will ensure that agricultural producers are fairly and adequately awarded for reduced GHG emissions and increased sequestration, and that the procedures are not overly burdensome or onerous, which would limit participation by producers.

- Develop and promote regional and state-specific approaches to enhance soil C stocks, including through the use of biochar, tailored to the agricultural activities, climate, soils, and economies particular to each.

\section{MANAGEMENT IMPLICATIONS}

Management practices are highly important to maintain, utilize, and improve the remaining and/or additional grazing lands within each region and state. The goal is to protect soil, water, and air quality, and wildlife habitat to which existing stocks of and sequestration of SOC contribute importantly. Rates of SOC sequestration vary with climate, soil, and management. Planning efforts to improve management are likely to have a greater impact if done at the watershed, state, or local level and with the active participation by land managers and owners. The expected environmental benefits provided through such efforts include the maintenance and well-being of immediate and surrounding soil and water resources, air quality, human and wildlife habitat, and esthetics. Management planning and implementation on grazing lands contributes to the economic well-being of those living on the land, to trade, and to exchange of goods and services derived from them at local, regional, or national levels.

Presently there are no regional or state mandatory policies that recognize soil $\mathrm{C}$ sequestration by grazing lands as a certifiable offset. Important opportunities exist to sequester soil C in grazing lands, but efforts to do so need to be designed based upon type of ecosystem, especially if eventually included within mandatory emissions reductions policies. Currently there is an increasing focus of governments to develop and implement mandatory GHG emissions reductions to combat global climate change. If such reductions become mandatory there are important opportunities for landowners and producers to evaluate voluntary offset activities to undertake to enhance rangeland soil C stocks and associated ecosystem benefits. Although more research and factual information is needed, there already exist guidelines and emerging policy and program support to utilize grazing lands to provide both environmental benefits to society and economic benefits to landowners, downstream towns and cities, and for export markets. At present there are existing programs and legislation, as well as voluntary markets with the potential to advance environmental and economic benefit goals within grazing lands and their associated communities.

\section{LITERATURE CITED}

Abril, A., AND E. H. Bucher. 2001. Overgrazing and soil carbon dynamics in the western Chaco of Argentina. Applied Soil Ecology 16:243-249. 
BANKS, J. 2008. The Lieberman-Warner Climate Security Act-S.2191: a summary of modeling results from the National Energy Modeling System. Available at: http://www.catf.us/publications/presentations/CATF_LWCSA_Short_Hill_ Briefing_with_CAFE.pdf. Accessed 27 May 2009.

Burke, I. C., W. K. Lauenroth, and D. G. Mllchunas. 1997. Biogeochemistry of managed grasslands in central North America. In: E. A. Paul, K. Paustian, E. T. Elliott, and C. V. Cole [EDS.]. Soil organic matter in temperate agroecosystems: long-term experiments in North America. Boca Raton, FL, USA: CRC Press. p. 85-102.

Conant, R. T., K. Paustian, and E. T. Elloott. 2001. Grazing land management and conversion into grazing land: effects on soil carbon. Ecological Application 11:343-355.

Derner, J. D., D. D. Briske, and T. W. Boutton. 1997. Does grazing mediate soil carbon and nitrogen accumulation beneath $\mathrm{C} 4$ perennial grasses along an environmental gradient? Plant and Soil 191:147-156.

Economic Research Service of the US Department of Agriculture [USDA]. 2007. Conservation policy: farmland and grazing land protection programs. Available at: http://www.ers.usda.gov/Briefing/ConservationPolicy/farmland.htm. Accessed 27 May 2009.

[FAO] Food and Agricultural Organization of the United Nations. 2004. FaO statistical databases. Available at: http://faostat.fao.org/site/395/default.aspx. Accessed 27 May 2009.

[FA0] Food and Agricultural Organization of the United Nations. 2009. Grasslands: enabling their potential to contribute to greenhouse gas mitigation. Available at: http://unfccc.int/resource/docs/2009/awglca6/eng/misc05.pdf. Accessed 2 July 2009.

Feng, J., L. A. Kurkalova, C. L. Kling, and P. W. Gassman. 2007. Transfers and environmental co-benefits of carbon sequestration in agricultural soils: retiring agricultural land in the Upper Mississippi River Basin. Climate Change $80: 1-2,91-107$.

Follett, R. F., J. M. KImBle, and R. LaL. 2001a. The potential of US grazing lands to sequester soil carbon. In: R. F. Follett, J. M. Kimble, and R. Lal [EDS.]. The potential of US grazing lands to sequester carbon and mitigate the greenhouse effect. Boca Raton, FL, USA: Lewis Publishers. p. 401-430.

Follett, R. F., J. M. KImBLE, and R. LAL [EDS.]. 2001b. The potential of US grazing lands to sequester carbon and mitigate the greenhouse effect. Boca Raton, $\mathrm{FL}$, USA: Lewis Publishers. $442 \mathrm{p}$.

Follett, R. F., S. E. Samson-Liebig, J. M. Kimble, E. G. Pruessner, and S. W. Waltman. 2001c. Carbon sequestration under the conservation reserve program in the historic grazing land soils of the United States of America. In: R. Lal [ED.]. Soil carbon sequestration and the greenhouse effect. Madison, WI, USA: Soil Science Society of America, Special Publication 57.

Follett, R. F., and G. E. Schuman. 2005. Grazing land contributions to carbon sequestration (invited Keynote paper for the 2005 International Grassland Congress, Belfast, Ireland). In: D. A. McGilloway [ED.]. Grazingland: a global resource. Wageningen, The Netherlands: Wageningen Academic Publishers. $p$. 266-277.

Follett, R. F., and S. R. Wilkinson. 1995. Nutrient management in forages. In: R. F. Barnes, D. A. Miller, and C. J. Nelson [EDS.]. Forages. Volume II. Ames, IA, USA: Iowa State University Press. $357 \mathrm{p}$.

Frank, A. B. 2004. Six years of $\mathrm{CO}_{2}$ flux measurements for moderately grazed mixed-grass prairie. Environmental Management 33(Suppl 1):S426-S431.

Franzluebbers, A. J., J. A. Stuedemann, H. H. Schomberg, and S. R. Wilkinson. 2000. Soil organic $C$ and $N$ pools under long-term pasture management in the Southern Piedmont USA. Soil Biology \& Biochemistry 32:469-478.

Fuhlendorf, S. D., H. Zhang, T. R. Tunnell, D. M. Engle, and A. F. Cross. 2002. Effects of grazing on restoration of southern mixed prairie soils. Restoration Ecology 10:401-407.

Gebhart, D. L., H. B. Johnson, H. S. Mayeux, and H. W. Polley. 1994. The CRP increases soil organic carbon. Journal of Soil and Water Conservation 49:374-377.

Greenhalgh, S., and A. Sauer. 2003. Awakening the dead zone: an investment for agriculture, water quality and climate change. Issue brief, World Resources Institute. Available at: http://www.wri.org/publication/awakening-dead-zone- investment-agriculture-water-quality-and-climate-change. Accessed 25 May 2008.

Henderson, D. C., B. H. Ellert, and M. A. Naeth. 2004. Grazing and soil carbon along a gradient of Alberta rangelands. Journal of Range Management 57:402-410.

Hibbard, K. A., S. Archer, D. S. Schimel, and D. W. Valentine. 2001. Biogeochemical changes accompanying woody plant encroachment in a subtropical savannah. Ecology 82:1999-2011.

Jenkinson, D. S. 1988. Soil organic matter and its dynamics. In: A. Wild [ed.]. Russell's soil conditions and plant growth. New York, NY, USA: John Wiley \& Sons. $991 \mathrm{p}$.

Kimble, J. W., C. W. Rice, D. Reed, S. Mooney, R. F. Follett, and R. Lal. 2007. Soil carbon management: economic, environmental, and societal benefits. Boca Raton, FL, USA: CRC Press, Taylor \& Francis Group. 268 p.

Kononova, M. M. [ED.]. 1961. The natural factors of humus formation. In: Soil organic matter: its nature, its role in soil formation and in soil fertility. New York, NY, USA: Pergamon Press. p. 203-230.

Kraxner, F., G. Adler, E. Angenendt, K. Aoki, G. Armstrong, J. Balkovic, R. Baritz, P. Benítez, D. Blank, R. Bujnovsky, S. De Cara, M. Fuchs, 0. Franklin, P.-A. Jayet, T. Johns, S. Leduc, M. J. Lexer, I. McCallum, E. Moltchanova, L. Montanarella, B. Müller, M. Obersteiner, K. Poltarska, E. Rametsteiner, W. Rammer, D. Rokityanskiy, B. Schlamadinger, E. Schmid, U. A. Schneider, D. E. Schwab, R. Seidl, R. Skalsky, V. Stolbovoy, K. Strassmann, J. Utermann, J. Yan, and J. ZedDIES. 2007. Integrated sink enhancement assessment (INSEA): main achievements and results. Laxenburg. Austria: International Institute for Applied Systems Analysis. Available at: http://www.iiasa.ac.at/Research/FOR/ papers/insea/INSEA-results.pdf. Accessed 27 May 2009.

Kuzyakov, Y., I. Subbotina, C. Haioing, I. Bogomolova, and X. Xu. 2009. Black carbon decomposition and incorporation into soil microbial biomass estimated by ${ }^{14} \mathrm{C}$ labeling. Soil Biology \& Biochemistry 41:210-219.

LAL, R. 2001. The physical quality of soil on grazing lands and its effects on sequestrating carbon. In: R. F. Follett, J. M. Kimble, and R. Lal [EDS.]. The potential of US grazing lands to sequester carbon and mitigate the greenhouse effect. Boca Raton, FL, USA: Lewis Publishers. p. 249-266.

LAL, R. 2004. Soil carbon sequestration impacts on global climate change and food security. Science 304:1623-1627.

LAL, R. 2007. Carbon management in agricultural soils. Mitigation and Adaptation Strategies for Global Change 12:303-322.

LAL, R., R. F. Follett, AND J. M. KImBlE. 2003. Achieving soil carbon sequestration in the United States: a challenge to policy makers. Soil Science 168:827845 .

Lecain, D. R., J. A. Morgan, G. E. Schuman, J. D. Reeder, and R. H. Hart. 2000. Carbon exchange of grazed and ungrazed pastures of a mixed grass prairie. Journal of Range Management 53:199-206.

Lehmann, J., J. Gaunt, and M. Rondon. 2006. Biochar sequestration in terrestrial ecosystems - a review. Mitigation and Adaptation Strategies for Global Change 11(2):403-427.

LIAO, J. D. 2004. Woodland development and soil carbon and nitrogen dynamics and storage in a subtropical savanna ecosystem [dissertation]. College Station, TX, USA: Texas A\&M University. $174 \mathrm{p}$.

Mayeux, H. 2001. Forward. In: R. F. Follett, J. M. Kimble, and R. Lal [eds.]. The potential of US grazing lands to sequester carbon and mitigate the greenhouse effect. Boca Raton, FL, USA: Lewis Publishers. p. xxv-xxix

McCarL, B. 2007. Analysis of the impacts of a carbon cap on net farm income, a modeling analysis prepared for the 21st Century Agriculture Policy Project. In: Senator Bob Dole and Senator Tom Daschle [EDS.]. Competing and succeeding in the 21st century: new markets for American agriculture. Washington, DC, USA: 21st Century Agriculture Project. $74 \mathrm{p}$.

McCarl, B., and U. A. Schneider. 2001. Climate change: greenhouse gas mitigation in US agriculture and forestry. Science 294(5551):2481-2482.

McKinsey \& Company. 2007. Reducing US greenhouse gas emissions: how much at what cost? US greenhouse gas abatement mapping initiative, executive report. Washington, DC, USA: McKinsey \& Company.

Mooney, S., AND J. Williams. 2007. Private and public values from soil carbon management. In: J. M. Kimble, C. W. Rice, D. Reed, S. Mooney, R. F. Follett, 
and R. Lal [EDS.]. Soil carbon management: economic, environmental and societal benefits. Boca Raton, FL, USA: CRC Press. p. 67-96.

Mortensen, M. C., G. E. Schuman, and L. J. Ingram. 2004. Carbon sequestration in rangelands interseeded with yellow-flowering alfalfa (Medicago sativa ssp. falcata). Environmental Management 33(Suppl):S475-S481.

National Agricultural Statistics Service of USDA. 2006. Statistics on cattle, hogs, and sheep. In: Agricultural statistics. Washington, DC, USA: US Government Printing Office. p. VII-1-VII-62.

[NRCS] Natural Resources Conservation Service of USDA. 1992. Instructions for collecting 1992 National Resources Inventory sample data. Washington, DC, USA: USDA-NRCS. $204 \mathrm{p}$.

[NRCS] Natural Resources Conservation Service of USDA. 1997. Announcement of the NRCS Environmental Credit Trading Information series: carbon credit trading on rangelands (NB.190.7.17, ECS). Available at: ftp://ftp-fc.sc.egov. usda.gov/WA/Intranet/Bulletins/O7Bulletins/WA190_7_2_b.pdf. Accessed 2 December 2009.

[NRCS] Natural Resources Conservation Service of USDA. 2007. Environmental credit trading information series: carbon credit trading on rangelands. Available at: http://policy.nrcs.usda.gov/search.aspx?q=Environmental\% 20credit\%20trading\%20on\%20rangelands. Accessed 27 May 2009.

[NRCS] Natural Resources Conservation Service of USDA. 2008. Global climate change: reducing greenhouse gas emissions and sequestering carbon. Available at: $<$ http://soils.usda.gov/survey/global_climate_change.html $>$. Accessed 27 May 2009.

Nyborg, M., E. D. Solberg, and S. S. Malhi. 1994. Soil C content under bromegrass increased by $\mathrm{N}$ and $\mathrm{S}$ fertilizer applications. In: Proceedings 31st Annual Alberta Soil Science Workshop, Edmonton, Alberta, Canada. p. 325-328.

OLSSON, L., AND J. ARdö. 2002. Soil carbon sequestration in degraded semiarid agro-ecosystems-perils and potentials. Ambio 31:471-477.

OrszaG, P. R. 2007. Approaches to reducing carbon dioxide emissions, CBO testimony before the Committee on the Budget, US House of Representatives. Available at: http://www.cbo.gov/ftpdocs/87xx/doc8769/11-01-C02Emissions. htm. Accessed 27 May 2009.

Orszag, P. R. 2008. Letter to Senate Agriculture Committee Chairman Tom Harkin. Washington, DC, USA: Congressional Budget Office, US Congress.

Pattanayak, S. K., A. Sommer, B. C. Murray, T. Bondelid, B. A. McCarl, and D. Gillig. 2002. Water quality co-benefits of greenhouse gas reduction incentives in US agriculture. Final report. Washington, DC, USA: USEPA. 28 p.

Plantinga, A. J., AND J. Wu. 2003. Co-benefits from carbon sequestration in forests: evaluating reductions in agricultural externalities from an afforestation policy in Wisconsin. Land Economics 79(1):74-85.

Potter, K. N., H. A. Torbert, H. B. Johnson, and C. R. Tischler. 1999. Carbon storage after long-term grass establishment on degraded soils. Soil Science 164:718-725.

Reeder, J. D., and G. E. Schuman. 2002. Influence of livestock grazing on C sequestration in semi-arid mixed-grass and short-grass rangelands. Environmental Pollution 116:457-463.

RICE, C. W. 2000. Soil organic $\mathrm{C}$ and $\mathrm{N}$ in rangeland soils under elevated $\mathrm{CO}_{2}$ and land management. In: Proceedings, advances in terrestrial ecosystem carbon inventory, measurements, and monitoring, October 3-5, 2000. Raleigh, NC, USA: USDA-ARS, USDA-FS, USDA-NRCS, USDOE, NASA, and National Council for Air and Stream Improvement. $83 \mathrm{p}$.

Schnabel, R. R., A. J. Franzluebbers, W. L. Stout, M. A. Sanderson, and J. A. Stuedeman. 2001. Effects of pasture management practices. In: R. F. Follett, J. M. Kimble, and R. Lal [EDS.]. The potential of US grazing lands to sequester carbon and mitigate the greenhouse effect. Boca Raton, FL, USA: Lewis Publishing. p. 291-322.

Schuman, G. E., and J. D. Derner. 2004. Carbon sequestration by rangelands: management effects and potential. CD-ROM. In: Proceedings of the Western
Regional Cooperative Soil Survey Conference, 13-17 June 2004, Jackson, WY, USA.

Schuman, G. E., J. D. Reeder, J. T. Manley, R. H. Hart, and W. A. Manley. 1999. Impact of grazing management on the carbon and nitrogen balance of a mixed-grass rangeland. Ecological Applications 9:65-71.

Scow, K. M. 1997. Soil microbial communities and carbon flow in agroecosystems. In: L. E. Jackson [ed.]. Ecology in agriculture. San Diego, CA, USA: Academic Press. p. 367-413.

Searchinger, T., R. Heimlich, R. A. Houghton, F. Dong, A. Elobeid, J. Fabiosa, S. Tokgoz, D. HAYES, AND T. H. Yu. 2008. Use of US croplands for biofuels increases greenhouse gases through emissions from land use change. Science 319(5867):1235-1238.

Sobecki, T. M., D. L. Moffitt, J. Stone, C. D. Franks, and A. G. Mendenhall. 2001. A broad-scale perspective on the extent, distribution, and characteristics of US grazing lands. In R. F. Follett, J. M. Kimble, and R. Lal [EDS.]. The potential of US grazing lands to sequester carbon and mitigate the greenhouse effect. Boca Raton, FL, USA: Lewis Publishers. p. 21-63.

Stahl, P. D., J. D. Anderson, L. J. Ingram, G. E. Schuman, and D. L. Mummey. 2003. Accumulation of organic carbon in reclaimed coal mine soils of Wyoming. In: R. I. Barnhisel [ED.]. Working together for innovative reclamation, 20th Annual Meeting, American Society of Mining and Reclamation, June 3-6, Billings, MT. Lexington, KY, USA: American Society of Mining and Reclamation. p. 1206-1215.

TATE, R. L., III. 1987. Soil organic matter: biological and ecological effects. New York, NY, USA: John Wiley \& Sons. 291 p.

Teague, W. R., J. K. Foy, B. T. Cross, and S. L. Dowhower. 1999. Soil carbon and nitrogen changes following root-plowing of rangeland. Journal of Range Management 52:666-670.

Thurow, T. L., W. H. BlackBuRn, and C. A. TAYLOR JR. 1988. Infiltration and inter-rill erosion responses to selected live-stock grazing strategies, Edwards Plateau, Texas. Journal of Range Management 41:296-302.

[UNFCCC] United Nations Framework Convention on Climate Change. 2008. Challenges and opportunities for mitigation in the agricultural sector: technical paper. FCCC/TP/2008/8. Available at: http://unfccc.int/resource/docs/2008/tp/08.pdf. Accessed 3 December 2009.

[USDOE] US Department of Energy. 2004. Carbon sequestration. Available at: http:// cdiac2.esd.ornl.gov/. Accessed 27 May 2009.

[USDOE] US Department of Energy. 2006. US Climate Change Technology Program: strategic plan. Washington, DC, USA: US Climate Change Technology Program. DOE/PI-0005.

[USePA] US Environmental Protection Agency Office of Atmospheric Programs. 2008. EPA analysis of the Lieberman-Warner Climate Security Act of 2008: S.2191. Washington, DC, USA: 110th Congress. 193 p.

US House of Representatives. 2009. American Clean Energy and Security Act of 2009. Available at: http://energycommerce.house.gov/Press_111/20090515/ hr2454.pdf. Accessed 2 July 2009.

Van den Pol-Van Dasselaar, A., and E. A. Lantinga. 1995. Modelling the carbon cycle of grazing lands in the Netherlands under various management strategies and environmental conditions. Netherlands Journal of Agricultural Science 43:183-194.

West, C. P., A. P. Mallarino, W. F. Wedin, and D. B. Marx. 1989. Spatial variability of soil chemical properties in grazed pastures. Soil Science Society of America Journal 53:784-789.

ZuLAuf, C. R. 2005. Farm Program spending: a historical perspective. Columbus, $\mathrm{OH}$, USA: Department of Agricultural, Environmental and Development Economics, College of Food, Agricultural, and Environmental Sciences, Ohio State University. AEDE-RP-0049-05. 9 p. 